\title{
Vegetative Response under Various Grazing Management Systems in the Edwards Plateau of Texas
}

\section{PATRICK O. REARDON AND LEO B. MERRILL}

Highlight: Forage production under five different grazing management schemes was compared after 20 years of treatment in the Edwards Plateau region of Texas. Results from this study showed that: (1) a more dense ground cover does not always result in higher forage production; (2) forage yields and litter accumulation were lower on a natural area than under deferred rotation or light grazing; (3) greatest amounts of decreaser plants were found in deferred rotation pastures; (4) natural areas have limited value in range research since they do not respond in comparative patterns; and (5) the 4-pasture deferred rotation system produced the most desirable livestock and wildlife habitat for the Edwards Plateau region of Texas.

The influence of grazing by livestock and wildlife on native rangelands and forest lands has received considerable attention for many years. Even more recently, the subject of "wilderness areas" or "natural areas"

The authors are assistant professor, Texas A\&M University Agricultural Research and Extension Center at Uvalde, and professor in charge of the Texas A\&M University Research Station at Sonora.

Manuscript received May 16,1975 has been studied and discussed. Some authorities feel that these areas, where particularly all domestic livestock grazing is eliminated, will provide a valuable tool for future biological research and education (Bormann, 1966; Brower, 1960; Emlen, 1964; Ripley, 1965). Other authorities have found that "ungrazed areas" do not necessarily respond as favorably as areas which have been properly managed (Duvall and Linnartz, 1967; Johnston,
1961; Marquiss and Lang, 1969; Pearson, 1965). Costello and Turner (1951) found that after 30 years of complete rest from grazing only a small difference in forage composition existed and that major forage adjustments occur rather slowly.

A livestock and wildlife grazing study was initiated on the Texas A\&M University Agricultural Research Station at Sonora, Tex., in 1949. This study includes a pasture which has been ungrazed by livestock or whitetailed deer (Fig. 1) and an area which has been grazed only by deer for this period. These two areas were included for comparison purposes and are considered "natural areas." Other pastures include those which are grazed lightly (16 animal units (AU)/section or per 640 acres), moderately grazed pastures 


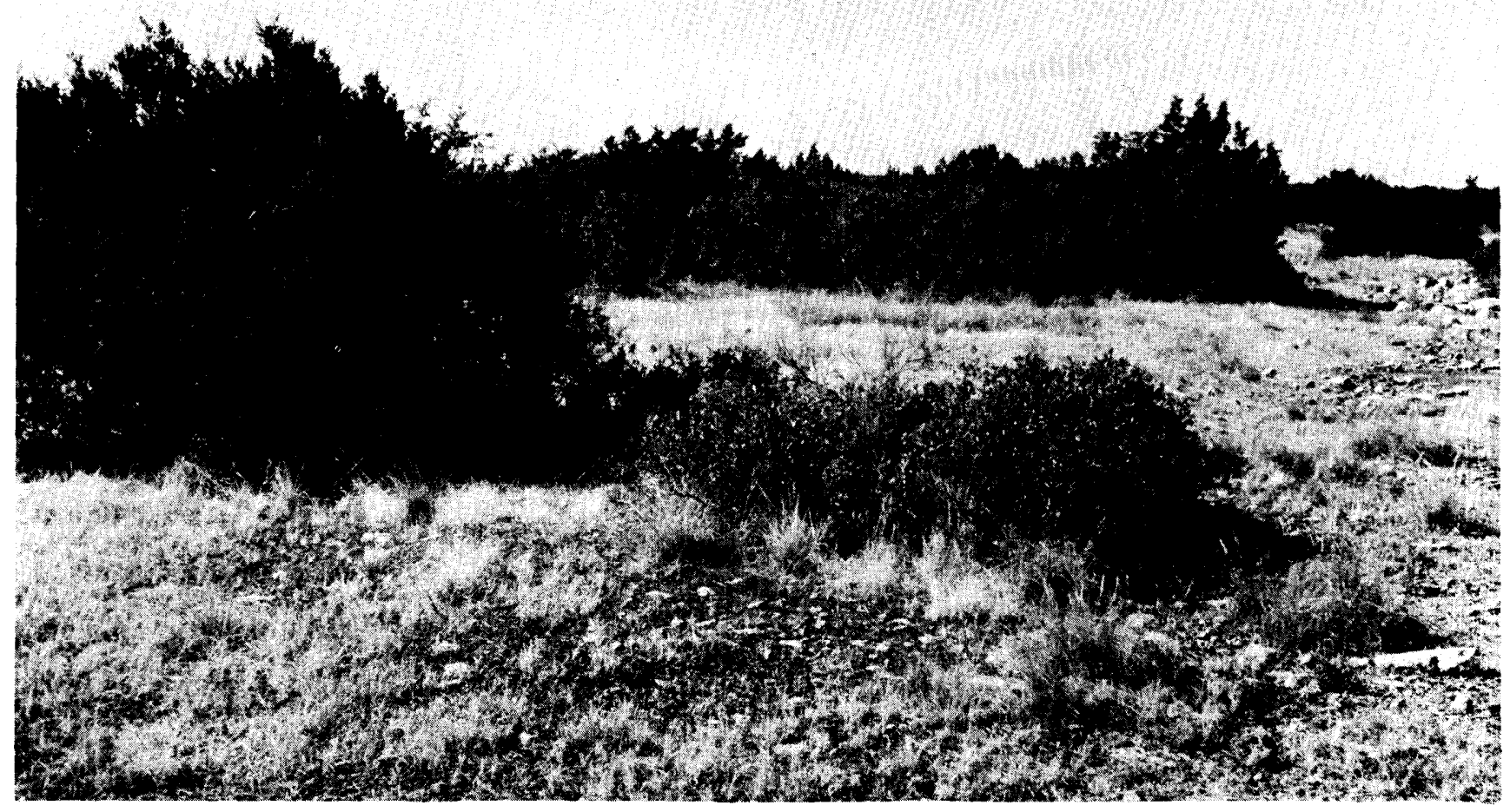

Fig. 1. Natural area site after 20 years of deferment from white-tailed deer and livestock grazing.

(32 AU/section), heavily grazed pastures (48 AU/section), and four deferred rotation pastures (32 or 43 AU/section) (Fig. 2).

Evaluations of yearly vegetation surveys made on the Sonora Research Station have shown that the gross density or total ground cover on the hcavily grazed pastures stocked with cattle, sheep, and goats might be higher than under other systems of grazing (Merrill and Reardon, 1966). It also appeared that the livestock and deer-livestock exclosures might have more dry organic matter and more climax or decreaser vegetation than pastures in the deferred rotation system. Clarification of these observations was essential to designing future research programs and making recommendations to landowners. Maintenance of, or improvement toward, climax vegetation along with high wildlife populations should be a desirable goal. Merrill et al. (1957) reported that white-tailed deer populations remained low with continuous heavy livestock grazing and high with a 4-pasture deferred rotation system. This suggests that wildlife, recreation, and esthetic values need not be sacrificed for good livestock management and vice versa. Therefore, the objectives of this study were: (1) to compare forage yields and litter accumulation under various grazing and nongrazing management schemes; (2) to determine some of the limitations of a natural area in rangeland research studies.

\section{Study Area and Procedures}

This study was set up to evaluate

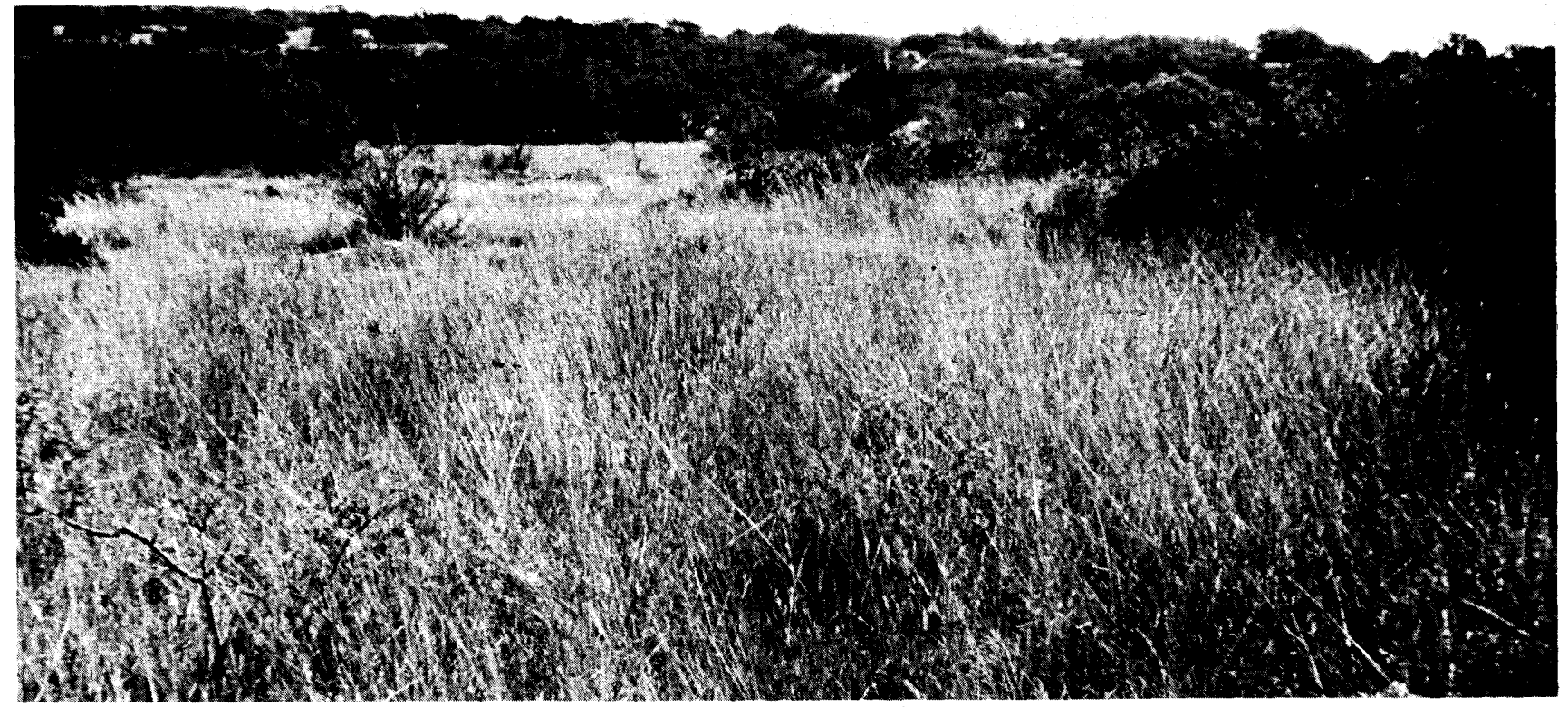

Fig. 2. Four-pasture deferred rotation site after 20 years of treatment. 
vegetation production on "natural areas" as well as areas grazed by domestic livestock and wildlife. Five different systems of management were compared. They were: continuous heavy grazing with cattle, sheep, and goats at $48 \mathrm{AU} /$ section; continuous light grazing with cattle, sheep, and goats at $16 \mathrm{AU} / \mathrm{section}$; complete rest from livestock and deer grazing (deerlivestock exclosure); complete rest from livestock with only deer grazing (livestock exclosure); and a moderately grazed 4-pasture deferred rotation system stocked with cattle, sheep, and goats. The deferred rotation pastures were originally grazed at 32 AU/section, but in 1959 the rate was increased to $43 \mathrm{AU} /$ section because excess plant material was being produced. The clipping results from the 4-pasture rotation pastures were averaged and included as one grazing system. All stocking rates are based on a 12-month calendar year.

Forage yields were determined by clipping $20\left(9.6 \mathrm{ft}^{2}\right)$ plots in each pasture and converting to $\mathrm{lb} / \mathrm{acre}$ by weighing the air-dried materials in grams and multiplying by 10 . The plant materials were divided into four groups, which include: decreasers; increasers and others; forbs and weeds; and dry organic matter or litter. According to the accepted definition, decreaser plants are those which decrease under excessive grazing pressure. Increasers are plants which increase when decreasers decrease, until they begin to decrease because of excessive grazing. Weeds were put into a separate group and were not classified as to whether they were desirable or undesirable. The dry organic matter included all dead grass, weeds, tree leaves, and manure. No tree limbs or twigs were included.

Forage production was sampled during the fall, following 5 years of dry weather and following a very dry summer in which only 3.8 inches of rainfall fell in the preceding 5 months. All samples were taken from pastures which were being grazed under their normal grazing scheme.

\section{Results and Discussion}

Forage yields are reported in Table 1. It can be noted that the yield from the decreasers was highest in the rotation pastures and lower in the lightly grazed and in both the exclosure pastures. This suggests that the deferred rotation system allows the better forage plants to become more numerous and more vigorous. Lower yields in both exclosures suggest that decreaser plants need some type of grazing in
Table 1. Plant yields (lb/acre) under various grazing management systems.

\begin{tabular}{|c|c|c|c|c|c|}
\hline \multirow[b]{2}{*}{ Type of forage } & \multicolumn{5}{|c|}{ Pasture treatment } \\
\hline & $\begin{array}{l}48 \mathrm{AU} / \\
\text { section }\end{array}$ & $\begin{array}{l}16 \mathrm{AU} / \\
\text { section }\end{array}$ & $\begin{array}{l}\text { Livestock } \\
\text { exclosure }\end{array}$ & $\begin{array}{c}\text { Deer- } \\
\text { livestock } \\
\text { exclosure }\end{array}$ & $\begin{array}{l}\text { 4-pasture } \\
\text { deferreú } \\
\text { rotation }\end{array}$ \\
\hline $\begin{array}{l}\text { Decreaser plants } \\
\text { Increaser plants } \\
\text { Litter } \\
\text { Forbs and weeds }\end{array}$ & $\begin{array}{r}19 \mathrm{c}^{*} \\
418 \mathrm{c} \\
477 \mathrm{~b} \\
44 \mathrm{a}\end{array}$ & $\begin{array}{l}220 \mathrm{ab} \\
814 \mathrm{a} \\
839 \mathrm{ab} \\
115 \mathrm{a}\end{array}$ & $\begin{array}{l}173 \mathrm{~b} \\
741 \mathrm{ab} \\
754 \mathrm{ab} \\
127 \mathrm{a}\end{array}$ & $\begin{array}{l}254 \mathrm{ab} \\
517 \mathrm{bc} \\
535 \mathrm{ab} \\
116 \mathrm{a}\end{array}$ & $\begin{array}{c}369 \mathrm{a} \\
722 \mathrm{ab} \\
1007 \mathrm{a} \\
97 \mathrm{a}\end{array}$ \\
\hline Total & $958 \mathrm{c}$ & $1988 \mathrm{ab}$ & $1795 \mathrm{ab}$ & $1422 \mathrm{bc}$ & $2195 \mathrm{a}$ \\
\hline
\end{tabular}

* Numbers in a row followed by the same letter are not significantly different at the $5 \%$ level.

order to remain vigorous and productive.

An analysis of variance on the data revealed that there were significant differences in decreaser plant production among pastures. A Duncan's multiple range test at the 5\% level indicated that the decreaser plants in the rotation, deer-livestock exclosure, and light-grazed pastures were not significantly different from each other, but all were significantly greater than the heavy-grazed pasture. There was no significant difference between the livestock exclosure and the heavy. grazed pasture.

Increaser plants were found to be highest in the light-grazed pasture (Table 1). This is not surprising since it has been grazed on a yearlong basis and the lack of some type of deferment has not allowed the decreaser plants to come in as heavily as in the 4-pasture deferred rotation system. This lack of decreaser plants has allowed the increaser plants to remain vigorous and productive. Light grazing during the year also failed to remove as much forage as the relatively heavy use on the rotation pastures.

The difference in increaser plant production among lightly grazed, livestock exclosure, and rotation pastures was not significant, but all were significantly greater than the heavygrazed pastures. There was no significant difference between the deerlivestock exclosure and the heavygrazed pastures.

The yields from the forbs and weeds varied little among the five grazing systems (Table 1). In can be noted, however, that forb and weed production was lowest on the heavygrazed pasture. It was observed during the clipping operation that the forbs and weeds present on the heavy-grazed pasture were of very low quality or of little value as forage. In fact, about $90 \%$ of this material was bitterweed
(Hymenoxys odorata) a poisonous plant which causes death losses each year in this pasture. The forbs present in the rotation pastures were of much higher quality and several were actually decreaser plants and were included as such. The low amount of palatable forbs accounts for the fact that there were virtually no deer found in the heavy-grazed pastures, while there are at least $10 \mathrm{AU} /$ section of deer found on the rotation pastures (Merrill et al., 1957). This, of course, means that rotation pastures are actually being grazed at a higher rate than the heavygrazed pastures, but are still producing higher forage yields and much greater net profit per acre.

The dry organic matter or litter was found to be highest on the rotation pastures (Table 1). The deer-livestock exclosure which was not grazed for 20 years had little more litter than the heavy-grazed pasture. There are several possible reasons for this. One might be that the lack of growth stimulation brought about by the absence of grazing has caused a relatively unproductive or stagnant vegetative cover.

There was a significantly greater amount of litter in the rotation pastures than under heavy continuous grazing, but no other treatments showed any significant differences. However, Table 1 shows that there was nearly twice as much litter in the rotation pastures as in the areas completely deferred for 20 years.

Table 1 also shows the total organic matter, which is actually all four previously discussed groups combined into one. As can be seen, the rotation system has the highest amount of total organic matter, and the heavy-grazed pasture the lowest. Therefore, the high amount of ground cover or grass density noted in the heavy-grazed pastures (Merrill and Reardon, 1966) does not mean that there is more 
forage being produced but only that there is a high percentage of relatively low forage-producing grasses, such as curly mesquite, red grama, and others. This type of vegetation forms a relatively dense sod but makes little growth under heavy use or dry range conditions. There was no significant difference in total plant material between the deer-livestock exclosure and the heavy-grazed pastures.

There are two major conclusions which might be drawn from this study, one being that an ungrazed or natural area has certain limitations which must be considered before it is used for comparative research studies. Vegetation in these areas does not respond like areas which are grazed to some extent. The specific vegetative association may actually deteriorate after an extended period of deferment. The other conclusion is that the use of a grazing management system in this area, such as the 4-pasture deferred rotation system, will allow the development of a highly productive vegetation complex and the maintenance and improvement of both the livestock and wildlife habitat.

\section{Literature Cited}

Bormann, F. H. 1966. The need for a federal system of natural areas for scientific research. BioScience 16:585-586.

Brower, David (Ed.) 1960. The meaning of wilderness to science. Proc. 6th Biennial Wilderness Conf., Sierra Club, San Francisco. $130 \mathrm{p}$.

Costello, D. F., and G. T. Turner. 1941. Vegetation changes following exclusion of livestock from grazed ranges. J. Forest. 39:310-315.

Duvall, V. L., and N. E. Linnartz. 1967. Influence of grazing and fire on vegetation and soil of longleaf pine-bluestem range. J. Range Manage. 20:241-247.
Emlen, J. T. 1964. Wilderness and behavior research. BioScience 14:32-33.

Johnston, A. 1961. Comparison of lightly grazed and ungrazed range in the fescue grassland of Southwestern Alberta. Can. J. Plant Sci. 41:615-622.

Marquiss, R., and R. Lang. 1969. Vegetational composition and ground cover of two natural relict areas and their associated grazed areas in the Red Desert of Wyoming. J. Range Manage. 12:104-109.

Merrill, L. B., J. G. Teer, and O. C. Wallmo. 1957. Reaction of deer populations to grazing practices. Tex. Agr. Prog. $3: 10-12$.

Merrill, L. B., and P. O. Reardon. 1966. Influence of grazing management systems on vegetation composition and livestock reaction. U.S. Dep. Agr. Coop. State Exp. Sta. Ser. (C.S.E.S.S.) Progr. Rep. (Unpub.) 19 p.

Pearson, L. C. 1965. Primary production in grazed and ungrazed desert communities of eastern Idaho. Ecology 46:278-285.

Ripley, S. D. 1965. Appraising the prospects for science and learning. Amer. Sci. 53:44A-49A. 